\title{
THE NON-TERRITORIALITY OF AN ERUV: RITUAL BEARINGS IN JEWISH URBAN LIFE
}

\author{
Robert Y. G. BECHHOFER \\ University of Huddersfield \\ E-mail:ygbechhofer@gmail.com
}

Received 25 September 2016; accepted 20 April 2017

\begin{abstract}
This paper considers the definition and meaning of an $\operatorname{eruv}^{1}$ as "territoriality without sovereignty" in Jewish tradition (Fonrobert 2005). It begins by exploring the origin and development of the term eruv itself, as well as its applications in different urban settings. It distinguishes between, on the one hand, the "enclosure" of the eruv that is made up of various natural and artificial structures that define its perimeter and, on the other hand, the "ritual community" created by the symbolic collection of bread that is known as eruvei chatzeirot. It suggests that much of the controversy, including legal issues of separation of church and state, as well as emotional issues such as the charge of "ghetto-ization", surrounding urban eruvin (plural of eruv) may be connected to the identification of the area demarcated by an eruv as a "territoriality". It argues that the enclosure of an eruv is not in itself religious in nature but rather makes up a completely arbitrary and generic "space", and that it is only through and on account of the eruvei chatzeirot that this space becomes meaningful as a purely symbolic "place" one day a week (on the Sabbath). In the course of this analysis, it considers the one "weekday" on which an eruv may be significant - the Jewish holiday of Purim - and how on that day it may be a tool by which the area defined as part of a given city may be extended.
\end{abstract}

Keywords: urban landscape, city, public space, eruv, architectural environment of pedestrian street, creative interpretation.

\section{The Biblical and Talmudic origins of eruv}

The study of the eruv in the ritual life of cities reveals a complex and little understood aspect of Jewish tradition that has a particular bearing on the way urban spaces in contemporary cities are used and occupied. In describing the laws of the Jewish Sabbath, Scripture (Exodus 16: 29) forbids a person situated in a public domain (reshut ha-rabbim) to carry or convey objects any further than four cubits (Eruvin, Babylonian Talmud 48a). The Biblical context is the manna that sustained the Israelites in the desert. The verses explain that manna would not fall on the Sabbath so that the Israelites not have to collect, carry, and transport it that day. R. Samson Raphael Hirsch posits that the explicit Biblical ban on the inappropriate transportation of an object (most of the laws of the Sabbath are not explicit in the Bible but were transmitted orally) was necessary so as to underline that transporting an object is no less a creative activity than the other

\footnotetext{
1 Sometimes spelled 'eruv.
}

38 forms of activity proscribed on the Sabbath (Hirsch 2005: 284-287). ${ }^{2}$ As the public domain in the desert was an open expanse, one of the criteria of a reshut ha-rabbim is that it not be enclosed, which is defined as being surrounded by three or more walls.

According to Talmudic tradition (Eruvin, Babylonian Talmud 21b), King Solomon extended the prohibition to enclosed public areas that do not fall into the category of reshut ha-rabbim. ${ }^{3}$ At the same time it was stipulated that the Solomonic prohibition (as opposed to the Scriptural ban) could be remedied by an eruv.

The word eruv (plural: eruvin or eruvim) means "mixture" or "unification." In the Talmud, it refers

\footnotetext{
${ }^{2}$ See also (Bechhofer 1998: 119).

${ }^{3}$ There are several forms of land use that fit into this category. Generally, an area that is linked by proximity and usage to houses and other structures is defined as a private domain (reshut hayachid), while areas that are not directly linked to structures are defined as karmelit, a term that translates roughly into "halfbaked." See (Bechhofer 1998: 6-26) for a fuller analysis of the Sabbath domains and prohibitions and their remedies.
} 
to the symbolic amalgamation of all the residents in houses that surrounded a common courtyard via a common meal. This unification allows those residents to carry from their houses into the courtyard and vice versa. In common usage, the term eruv is a shortened form of the complete phrase eruvei chatzeirot, referring to "unifications of courtyards" (a chatzer is a courtyard, plural: chatzeirot).

As the areas to which it was applied were enclosed courtyards, the term eruv was originally unconnected to the enclosure of an area. It referred to the symbolic unification. This unification was (and still is) accomplished by setting aside a certain amount of bread before the Sabbath, pronouncing an appropriate blessing, and stating that this eruv permits residents and guests to carry to and from their homes to the common area, and from home to home as well. Through this mechanism, ritual enactments and their spatially enclosed settings are demonstrably bound and interconnected. Indeed, in the Talmud the term extends only to houses and courtyards. Carrying into, from, and within an area that encompasses streets was allowed, following proper enclosure, by a similar but different mechanism: shitufei mevo'ot, "partnership in streets" (a mavoi is an alley or a street, plural: mevo'ot). When a courtyard or street was populated by both Jews and non-Jews (or non-Sabbath-observing Jews), an additional mechanism was (and is) required: sechirat reshut, "renting of the domain" (sechirat means the "renting of") from those individuals who are not Sabbath-observant, either individually or collectively. ${ }^{4}$

The focal point of the enactment of eruvei chatzeirot was the collection of the bread:

R. Joshua said: Why do we make eruvei chatzeirot? For "pathways of peace" (darchei shalom). It once happened that a woman thought she was detested by another woman [who lived in the same courtyard]. The first woman sent her young son with the eruv [her contribution to the communal collection of bread] to the second woman. The second woman took the bread and hugged and kissed the boy. The boy went back to his mother and told her what happened. The first woman said: "She loves me so much? I did not know!" As a result they made peace between themselves. As Scripture (Proverbs 3:17) says: Its [the Torah's] ways are ways of pleasantness and all its pathways are peace (Eruvin, Jerusalem Talmud 3: 2).

\footnotetext{
${ }^{4}$ See (Bechhofer 1998): 103-118) for a fuller analysis of these mechanisms.
}

Only once, however, in the form of a verb, does the Talmud use the term eruv to refer to the enclosure. ${ }^{5}$ The first times we find it used in the form of a noun to reference to the enclosure that is a precondition for the eruvei chatzeirot are, in the East, in the 8th-century Babylonian Halachic work, Halachot Gedolot (Kayyara 1888: 127) and in the West in the 13th-century Italian Halachic work, Piskei HaRid (Di-Trani 1966: 44). ${ }^{6}$

\section{Contemporary urban Eruvin}

For thousands of years, however, cities were generally surrounded by walls. While there were concerns about breaks in the walls and gateways, few additional structures were necessary (see Fig. 1). Thus, to enable themselves to carry on the Sabbath within a city, the Jewish residents needed only to rent the right to carry from the authorities (sechirat reshut $)^{7}$ and perform the eruvei chatzeirot.

Over time, older cities outgrew their walls. Newer cities were built without walls altogether. These developments posed quandaries for the Jewish populations of urban areas.

We have very interesting examples from the Polish lands occupied by Prussia after 1795 and 1815, when reformers from Berlin came to these eastern regions and decided to start modernisation with the destruction of city walls - not knowing that in this process they also destroyed the existing eruvs (Schlör 2007: 2-3).

For the first time, Halachic (Jewish Law) authorities were forced to grapple with the challenge of effectively enclosing a city in a way that would be acceptable to the civil authorities. The least obtrusive and most economical Halachic method of enclosing an area is a tzurat ha-petach, "the form of a doorway". A tzurat ha-petach consists of two poles (the doorposts) with a wire across the top (the lintel) and the variations on that theme. The rationale of this solution is that a door frame is an Halachically valid form of enclosure (Eruvin, Babylonian Talmud 11b). Eruvin of this sort

\footnotetext{
${ }^{5}$ Eruvin, Babylonian Talmud 6a. The Talmud there considers whether certain structures can be used to make an eruv in a reshut ha-rabbim. The actual word eruv as a noun does not appear there. It appears in the form of a verb - me'arvin, "make an eruv".

${ }^{6}$ See also http://eruvonline.blogspot.co.il/2006/02/part-1a-variousissues-regarding.html. It would be interesting to explore whether the discrepancy reflects a discrepancy in the spreading of urban populations beyond ancient walls in Italy vs. Babylon.

${ }^{7}$ For an overview of the procedure see (Bechhofer 1998: 111-116). Some of my interest in eruv stems from my excitement at being present, as a young lad of 10, when in 1972 "Hempstead Town today symbolically leased a square mile of West Hempstead to an Orthodox Jewish Congregation" (Religion 1972). The term was twenty years for a consideration of one dollar.
} 


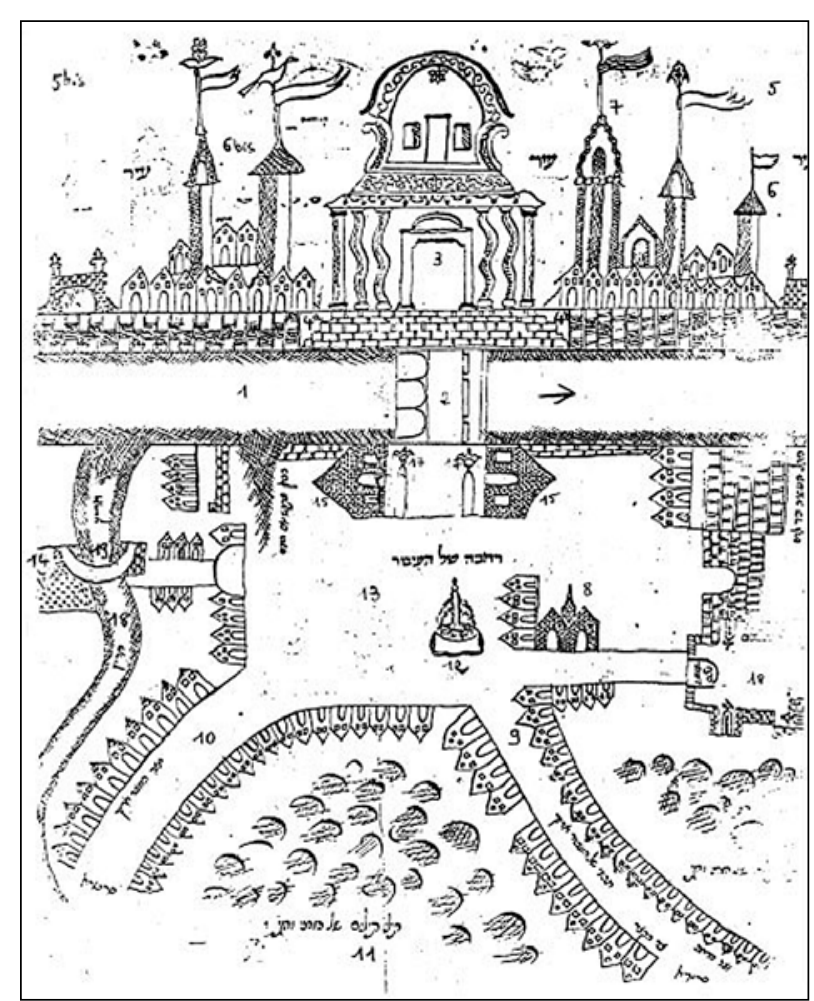

Fig. 1. The earliest known "eruv map" depicting the walls surrounding the city of Bayonne, Italy, ca. 1730

Source: Hutterer (2016).

enclose areas as small as a backyard and as large as entire neighborhoods or cities (see Fig. 2).

The invention of the telegraph and telephone and the resulting proliferation of poles and wires in metropolitan areas made this method especially prevalent and expedient. In ancient and Medieval cities (with their more clearly defined boundaries, gates, and thresholds), disputes and controversies were rare. Walls are walls. The development of complex utilitarian infrastructural elements in the modern city (such as electricity cables and poles) and their casting as parts of eruv perimeters has given rise to more disputes and controversies concerning the legality of contemporary eruvin from both Jewish and secular perspectives.

A communal or urban eruv usually entails little installation of wire and poles. For the most part, pre-existing structures serve as part of the communal enclosure (see Fig. 3). To utilize these pre-existing structures, urban eruvin often follow seemingly illogical patterns, such as including a sidewalk on one side of a street while excluding the sidewalk on the other side, cutting through alleys, or encompassing broad areas with few Jews. These structures are often actual walls: fences, embankments, riverbanks, sides of buildings, etc. Almost invariably, however, urban eruvin incorporate long spans of overhead cable and the poles to which this cable is attached. Each segment in a series of poles

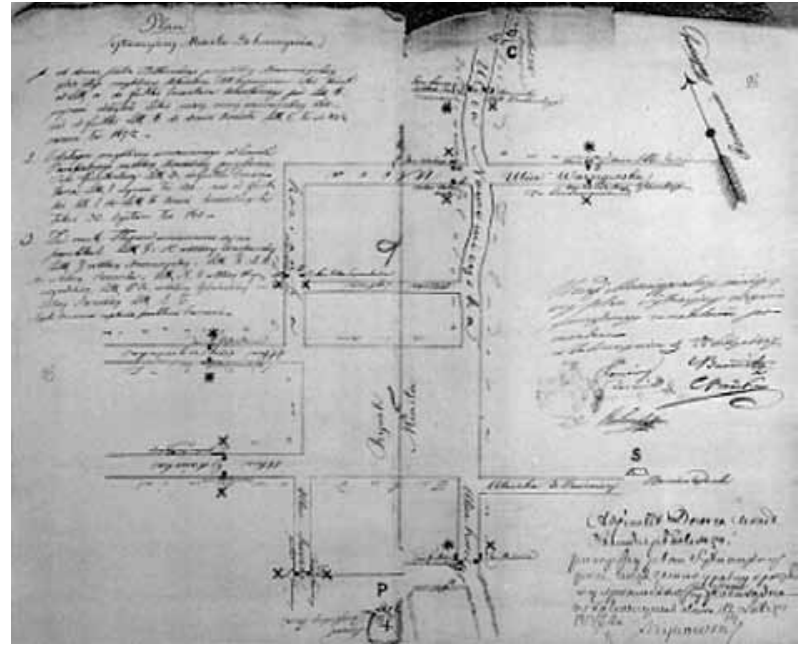

Fig. 2. An early map of a tzurat ha-petach based eruv Source: Bergman (2002).

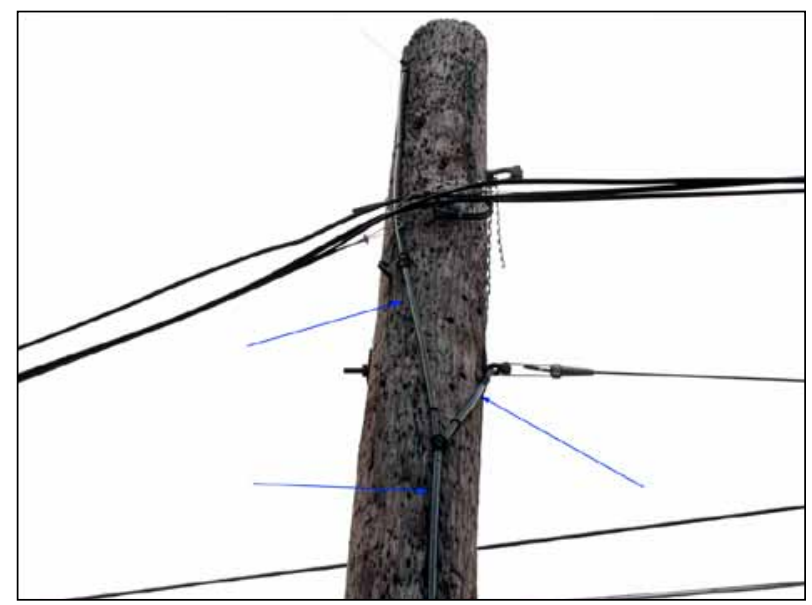

Fig. 3. The blue arrows highlight the "sideposts" for the overhead "lintel" in a utility pole tzurat ha-petach

Source: Rotenstein (2010).

with overhead wires is modified as needed so as to form a tzurat ha-petach.

Academic research often speculates on the spatial definitions and dispositions of the eruv throughout history, with particular emphasis on its role in validating Jewish urban life in a broadly secular society. These are not uniquely Jewish areas of research. One researcher (Smith 2007) draws a parallel to Searle's (1995) example of a primitive tribe that built an actual wall to demarcate its territory, which over time decayed into a line of stones that was still recognized as the tribal boundary.

The line of stones now has a function that is not performed in virtue of sheer physics but in virtue of collective intentionality.... The line of stones performs the same function as a physical barrier but it does not do so in virtue of its physical construction, but because it has been collectively assigned a 
new status, the status of a boundary marker

(Searle 1995: 40).

It is important to identify and define that "line of stones" and the "collective intentionality" as they emerge from the application of the ancient Solomonic traditions of eruv to the contemporary city, with its pre-existing instrumental (technologically driven) urban infrastructure. What appear in everyday urban life as prosaic - such as poles and fences - carry potentially problematic implications in mapping the dynamics of eruv communities in the contemporary city. Yet it is important to note that such mapping of communal activity is relevant and in effect only one day a week on the Sabbath. As Schlör states:

A certain space, which during the week has the same appearance and the same function for Jews and non-Jews, on the Sabbath changes its meaning for the Jews because of Jewish law, whereas for their non-Jewish neighbors it does not (Schlör 2007: 2).

\section{The eruv as a "territoriality"}

The identification of this thematic of a Jewish community - its "invisible" arrangement of symbolic relationships within the visible (and tangible) systems of a secularized and instrumental world - raises important questions about the capacity for such co-existence in an increasingly globalized and fragmentary age. For example, does such invisibility, except in the eyes of observant Jews, simply mask underlying conflicts and potential territorial divisions? Fonrobert (2005), however, advances the idea that an eruv actually creates "territoriality without sovereignty."

The rabbinic theorizing of the eruv community, or the ritual system of the eruv, can be read as a powerful way to think about the importance of neighborhood for conceiving of community. This, I would add, has particular importance in a diaspora situation. That is, a nationalist concept of collectivity assumes sovereign control over territory, and this control functions as a guarantee for the construction (or imagination) of national identity by the population living within the borders of that territory. The eruv does construct a collective identity with respect to space, but it does so in the absence of having control or any form of sovereignty over that space. On the contrary, it maps a collectivity symbolically into space over which it does not claim control, political or otherwise. It maneuvers around the existing structures of control. Playing off of Arjun Appadurai's analysis of the contemporary crisis of the concept of the nation state, due to the dynamics of globalization, as "sovereignty without territoriality," I would suggest that the eruv offers a powerful model of a territoriality without sovereignty and, as such, would have much to offer to the current discussions about diaspora cultures (Fonrobert 2005: 29).

This idea has ramifications. In our day and age, in which online "virtual communities" are often perceived as threats to "real communities" (such as when subversive and terrorist groups use their virtual communities for their own frightening and destructive ends), the spatial virtual community of the eruv may be perceived as an invasive and even oppressive network of exchange (specifically, a religious/orthodox community) that runs counter to the "safe" homogeneity and undifferentiated nature of modern urban space. The use of the term "sovereignty" in itself triggers such perceptions. For example, in his review of Medina's and Hepner's work on the spaces and places of terrorism, Roberts mentions: "Nationalist/separatist groups such as Hamas seek to force a change in Israeli policies for more sovereignty" (Roberts 2013: 106). The term “territoriality" is even more suspect:

In human territoriality, there were three basic territorial principles of efficiency: territoriality (which I will now simply describe as place) can increase efficiency by the way it (a) communicates rules at the boundary, (b) defines what things are intended to be controlled, and (c) enforces access to things (Sack 2010: 230).

As Sack (1986) puts it very succinctly right at the beginning of Human Territoriality: "Territoriality for humans is a powerful geographic strategy to control people and things by controlling area... Territoriality is a primary geographical expression of power" (Sack 1986: 5).

If an eruv delimits a certain territory for periodic appropriation, it "powerfully" imposes these characteristics on the area it encompasses. This imposition of a new character on a neighborhood will almost certainly lead to disputes and controversies. But does eruv, in fact, constitute territoriality?

\section{What does an eruv do?}

In an attempt to ground the modern urban eruv in ancient sources, Fonrobert (2004) examines the possible connections between the laws of eruvin and passages in the Dead Sea Scrolls found at Qumran. Inter alia, she also attempts to define the communality created by an eruv: 
The rabbinic 'eruv can then be described as a project of constructing, maintaining and re-enacting a collective identity in relation to the residential space of the mixed urban courtyard. Its purpose is to create neighborhoods of what might be considered as intentional co-habitation. Finally, read on the background of the Qumranic attempts to protect the boundaries of its collective, the rabbinic 'eruv appears as a concerted effort to formulate a theory of neighborhood (Fonrobert 2004: 67).

Fonrobert's definition has led subsequent writers to somewhat extreme analogies. ${ }^{8}$ Lees (2007), for example, writing about the controversy surrounding an eruv in Tenafly, New Jersey, acknowledges:

The devices that mark the existence of the invisible walls usually are undetectable by the uninformed eye - very thin wires attached to poles that might be placed, or exist in the midst of, numerous other poles for a variety of utilities. If you didn't know there was an eruv in a town, you would be unlikely to see such markers, and even if you did know, you might be at some pains to find them (Lees 2007: 45).

Accordingly, she asserts, the conflict in Tenafly cannot have been about the markers or the invisible walls. Rather, basing her understanding on Fonrobert, Lees asserts that the eruv was controversial because it created "a kind of residential commune." She posits that an eruv "excludes or distances non-Jews and co-resident Jews" and that this exclusion was at the heart of the bitter eruv controversies in Tenafly and elsewhere. She concludes with an interesting analogy:

The insistence of the Orthodox Jews of Tenafly upon their rights to be different, as symbolized by their demand for acceptance of their eruv, resonates with the insistence of diaspora groups in many areas of the world, particularly in Western Europe, where the general movement of the modern nation-state toward modernity (and secular government) has been challenged by the enormous influx of religiously committed immigrants. In some respects, then, the eruv resembles the headscarves of French Muslim

\footnotetext{
${ }^{8}$ In a later review essay (Fonrobert 2009), Fonrobert herself notes the pit into which writers often fall when they separate their theoretical agendas - creative as they may be - from the actual practices of eruvin "as the eruv disappears into total abstraction" (Fonrobert 2009: 163).
}

girls who have been demanding the right to wear them in public schools (Lees 2007: 67).

Lees' exploration of the definition of "Jewish space" in suburbia is based to a significant extent on the notion of an eruv as primarily an "invisible wall," with the secondary aspect of communality achieved by the symbolic joint ownership of food. This Jewish space could be construed as Fonrobert's territoriality without sovereignty. Yet her own analogy to the very visible headscarves worn by French Muslim girls highlights the very invisible walls of an eruv.

Moreover, Lees' premise is based on a misunderstanding of the notion of an invisible wall in Jewish law. This notion is captured by a well-known joke concerning another Jewish legal institution that makes use of "invisible walls":

My father, of blessed memory, used to tell a favorite joke: a jerry-built sukkah [the ritual temporary booth in which Jews celebrate the eponymous autumn holiday of Sukkos] was broken into by a Cossack who stole all the family belongings. The two yeshiva boys who discovered the break-in were totally puzzled by the theft. "How could he even get in?" one asked. "This [incomplete] wall is legally projected to the end; that vertical frame is legally projected to the ground. So where did the Cossack find an opening and get in?" To which the other answered: "You see, the Cossack is an ignoramus who did not know the law of the projection of the wall" (Greenberg 1993: 100).

Playfully presented, the point is nevertheless made: The Cossack is not an ignoramus. Virtual walls are virtual walls; they are legal loopholes, not real barriers that set off and exclude.

More importantly, these virtual walls are modern substitutions for the real walls of the ancient courtyard or city. The walls themselves - whether they are visible or invisible - have nothing to do with religion per sé. While in Judaism a wall can map ritual purposes - for example, a leper is to be excluded from the walls of a city, and the walls of Jerusalem defined the area in which sanctified tithes and sacrificial offerings may be eaten - the wall itself does not acquire religious significance, except, perhaps, as a powerful metaphor of Divine protection such as in the "walled garden of Eden" or the wall of "Heavenly Jerusalem." Walls are multipurpose. Unlike the Muslim headscarves, the walls of an eruv do not present exclusively religious functions.

Fonrobert's suggestion is also echoed and elaborated by Herz (2008), who links the territoriality 
accomplished by an eruv to the Holy Temple that stood in Jerusalem. Herz grounds his assertion in an unsourced creative homiletic discourse:

The city - referring to the displacement of the desert - is transformed by the eruv on the Sabbath into a representation of the Temple and thus from the public into the private domain. If the eruv area is understood as the Temple of Jerusalem, the outer area is the desert, and movement into the eruv is an act of wandering that culminates in the appropriation of a place (Herz 2008: 46).

Herz goes on to argue that the parameters of an eruv's invisible walls are derived from the parameters of the construction of the Holy Temple in Jerusalem, and that the eruv perimeter is meant to symbolically "'build' the Temple over the city". While his original homiletic insight is intriguing, Herz's premise is flawed. The primary source for any understanding of the symbolism of the eruv must be the Talmud, the primarily - and essentially exclusive - basis of subsequent Jewish law. The Talmud pays little attention to the walls - their existence is assumed. The focus is on the communal collection of bread. That collection, asserts the Talmud, is meant to bring peace and harmony to the community - not to make the eruv's space into a massive symbolic temple. ${ }^{9}$

Mann (2012) suggests a slightly different perspective, yet harks back to Fonrobert's framing the significance of an eruv in a "diaspora" situation (notwithstanding the fact that the Solomonic enactment of eruv precedes the exile and subsequent diaspora by hundreds of years).${ }^{10}$ She suggests that an eruv is a "portable spatial device; though produced through a specific set of geographic coordinates - doorways and sideposts", and that it makes up a "home" in a diaspora setting.

Looking at an eruv as a territoriality, a kind of Holy Temple, or even a home, implies that the nature of the

\footnotetext{
${ }^{9}$ Fonrobert (2005: 12-21) does consider the eruv as defined by the symbolism and significance of the collection of bread. Although some of her suggestions are conjectural, her analysis of the rabbinic sources is far-reaching and admirable. It is the leap of logic from the perception of the collection of bread as a "unification" to a perception of the eruv as a "territoriality" that I argue is a leap too far. ${ }^{10}$ I would argue that any discussion of the eruv should be anchored in the Talmudic texts from which such discussions emerge. It is on this basis that I argue here that the eruv, since it dates to Solomon, cannot be considered as framed in a diaspora situation. I recognize that this argument may seem ahistorical, as it takes the Talmud at face value and does not consider the problematic of the Talmud itself, which was framed in a Diasporic era and situation. I acknowledge that Fonrobert and Mann might counter that they are constrained to read all primary sources historically. I, in turn, would counter that their readings are conjectural, and as such require significant evidence that I find lacking. In contrast, my readings are minimalist, constrained by what we can ascertain from the texts themselves.
}

space contained within an eruv has somehow been transformed. None of the classic sources that necessarily serve as the basis for analyzing eruvin would seem to support these contentions. On the contrary, the origin of eruvin in walled courtyards and towns indicates that the perimeter of an eruv is entirely mundane. Moreover, the limited duration of an eruv - one day a week - indicates that no transformation is implied. The form and function of an eruv is analogous to the form and function of an enclosed park in which a picnic or carnival is being held. Using the definition of place as "a space with meaning and a distinct character" (Cowan 2005: 290), an eruv should be seen as defining the space that allows for the creation of a symbolic place by means of the eruvei chatzeirot and its companion procedure of sechirat reshut.

The non-territoriality of an eruv may be explained by reference to Lefebvre's linkage of the concepts of state, space and territory. As Brenner and Elden note, Lefebvre insists "that there is no state without a territory, and concomitantly, there is no territory without a state" (Brenner, Elden 2009: 362). The limited community formed by the eruv has none of the characteristics of "state space" (l'espace étatique) that Lefebvre includes in the "broad range of processes, transformations, conflicts and struggles associated with the modern state at all spacial scales" (Brenner, Elden 2009: 358). Moreover, although Jewish law abounds with "'absolute' spaces of precapitalist social formations, which were organized with reference to politico-religious differentiations among sacred and profane locations" (Brenner, Elden 2009: 358), an eruv does not fall into any of these categories either.

\section{Purim}

At first glance it would seem that Fonrobert's definition of an eruv as a territoriality may be sustained on the basis of an obscure application of the concept of eruv - one that extends beyond the laws of the Sabbath to which it is normally relevant.

The holiday of Purim is celebrated in the lunar month of Adar. On Purim, as part of the festivities, the Book of Esther, which relates the events that the holiday celebrates, is festively read evening and morning. The Book of Esther recounts that, in the hinterlands of the Persian empire, the salvation of the Jews from their enemies was celebrated on the $14^{\text {th }}$ day of Adar, while in the capital, Shushan (Susa), the celebration took place on the $15^{\text {th }}$ day of Adar. This difference was formalized in Jewish law by an enactment that residents of cities that were walled in ancient times (and that in this respect are similar to Shushan) read the Book of Esther the evening and morning of the $15^{\text {th }}$ 
day of Adar, while residents of all other locations read it the evening and morning of the $14^{\text {th }}$ day of Adar. Today, in the overwhelming majority of locations it is read on the $14^{\text {th }}$ day of Adar. The most notable exception is Jerusalem, in which it is read on the $15^{\text {th }}$ day of Adar. ${ }^{11}$

So long as the entire population of Jerusalem was ensconced within its ancient walls, the application of this law was straightforward. Beginning in the $19^{\text {th }}$ century, however, the population began extending outside the walls of the Old City. The Talmud deals with such a contingency, and states that in areas that are either physically or visually contiguous (samuch or nireh) to a walled city, the Book of Esther should also be read on the $15^{\text {th }}$ (Schnall 2011: 70). ${ }^{12}$

Beginning in the mid-20 $0^{\text {th }}$ century, however, Jerusalem began expanding far beyond what might be defined as contiguous. The question then arose whether the more remote neighborhoods of the metropolis should read the Book of Esther on the $14^{\text {th }}$ or the $15^{\text {th }}$ of Adar. One suggestion that was raised was to define the boundaries of the city by its eruv, regardless of the vastness of the area it encloses. This idea is examined by Schnall (2011):

This opinion has been advanced by $\mathrm{R}$. Shlomo Zalman Auerbach, R. Yosef Shalom Elyashiv, and others. ${ }^{13}$ According to this line of reasoning, any region surrounded by an eruv that also encompasses a walled city would observe Purim on the $15^{\text {th }}$ of Adar. Several arguments have been made to counter this position... As a result, some... have rejected the use of eruv vis-à-vis Purim and require true proximity for the rules of samuch and nireh (Schnall 2011: 70-71).

It would seem that the opinion that an eruv can demarcate a city for the purpose of reading the Book of Esther on the $15^{\text {th }}$ would sustain the notion of an

\footnotetext{
11 The law (see Megillah, Babylonian Talmud 2a) is that besides Shushan, only cities walled from the time of Joshua may read the Book of Esther on the $15^{\text {th }}$. This is because at the time of the Purim events, the Land of Israel - having been recently ravaged - was bereft of walled cities. Of course, there were many walled cities in the Land of Israel - both already standing and newly built - during the era of Joshua's conquest and division of the land. Thus, the Sages preserved the centrality of the Land of Israel even in regard to events that took place beyond its borders (Megillah, Jerusalem Talmud 1:1).

${ }^{12}$ This extension of the reach of a long-held tradition fuori le mura based on visible or spatial contiguity is diametrically opposed to the plan of Pope Julius II (1503-1513) for extra muros Rome:

Communicated through papal sermons and eulogies, this essentially humanist "project" enabled Rome to be reconceptualised as the redeemed city, whose physical transformations were visibly and spatially juxtaposed against the older and moribund counterparts of the medieval city (Temple 2011: 1).

13 From (Slonim 1979: 184).
}

eruv as a form of territoriality. It does not, however, sustain that notion on Fonrobert's terms. According to Fonrobert, the linkage of the eruv boundaries with the symbolic community of shared food creates a kind of "Jewish" territoriality - which would play into issues of church and state. The use of the eruv for Purim is as a "sovereignty without territoriality". The eruv functions like a secular wall, extending the sovereignty of the municipal entity to non-contiguous territories by virtue of the enclosure. Just as the walls of a city are not a function of a religious community, so too the eruv in this context functions without eruvei chatzeirot. Moreover, R. Auerbach's (1999: 220) essay on this issue relates specifically to the Hadassah Hospital in Ein Kerem, which, at the time (1964), was physically remote from the inhabited area of the Jerusalem municipality. Accordingly, part of his argument was that a city hospital is essential to a city, and that thousands of people travel daily back and forth from the main city to the hospital - and on that account, the tzurat ha-petach of the Jerusalem eruv could extend the parameters of the city to the hospital. ${ }^{14}$ In the case of Purim, the eruv walls serve a very different purpose. Their interaction with the l'espace étatique of the municipality may well define a Lefebvresque territoriality. A rough analogy may exist between the case of Purim and a case analyzed by Brenner and Eldan, that of "the Israeli 'wall" built in Palestinian territory" (Brenner, Eldan 2009: 366). ${ }^{15}$

\section{Another perspective on eruv}

While Fonrobert is the primary source for the perception of an eruv as territoriality without sovereignty, the question of the accuracy of such a judgment predates her formulation. It informs much of the literature concerning separation of church and state vs. accommodating an eruv. Researchers covering this question include Stoker (2003), who considers some of the issues raised in the Tenafly case. She contrasts the case of Tenafly, in which it was argued that "permanently affixing religious symbols to public property (in this case, utility poles)," violated the separation of church and state, with other cases that involved other issues. She suggests that these issues "are often a smoke screen for deeper community conflict".

In other locations, people have objected to eruvim on aesthetic grounds, claiming that

\footnotetext{
${ }^{14} \mathrm{R}$. Auerbach posits that even if the eruv were to be "down" on Purim, the law would be the same, as the extension of the eruv to the hospital as a demonstration of the intent to include the hospital in the municipal sphere remains in place in any event.

${ }^{15}$ See, however, Ballvè's (2011) critique of that analysis.
} 
they violate zoning laws. This aesthetic argument has been a key component of the ongoing eruv dispute in Barnet, England, where the suburban landscape requires not only the addition of wires but of poles from which to string them. Davina Cooper has argued that this style of opposition has deliberately sought to avoid the religion versus secularism question, in part so as not to make the campaign appear anti-Semitic. However, Cooper's analysis effectively demonstrates that the real dispute is not about the aesthetics of wires and poles but conflicting understandings of a community's self-image and which subgroups within the community should be allowed to shape that image... Eruv requests are contested in locations already marked by ethnic, religious, cultural, and other tensions and where an established and therefore "correct" community image is felt to be undermined by the eruv's presence (Stoker 2003: 21-23). ${ }^{16}$

If an eruv is a "territoriality without sovereignty," then it is natural to perceive its construction as "the imposition of religious views onto the secular public domain." But if the "walls" of an eruv are understood as inherently areligious, and that the locus of the symbolic place is the collection of bread, the space remains the secular public domain - for the Sabbath it is made into a place in the same way that, say, a party held in a gymnasium does not impinge upon its ongoing "real" function. Indeed, since an eruv does not disallow any form of usage within its perimeter, it is more precise to see it as a gymnasium that is in use as a gymnasium, while in the corner a quiet party is being held, unnoticed and unremarked. Vincent and Warf (2002) express this perspective:

The eruv suggests interventions in the city, which are small-scale, static and, for the most part, not material. Thus, it provides a model for pluralist uses of the city that do not exclude other readings of the same space (Vincent, Warf 2002: 49).

Vincent and Warf posit that the "symbolic content of eruvim" that has been perceived in various ways as a threat - even as "a threat to the mythical Enlightenment ideal of the culturally homogenous citizen bound by universal norms of rationality" - would be allevi-

\footnotetext{
${ }^{16}$ See also (Hecht 2007) for an overview of several contentious eruv controversies in the US and the UK. For a legal assessment of the legal issues in the Tenafly, NJ, case, see the essay by the lawyer who argued the case, Nathan Lewin, in (Lewin 2004).
}

ated by "the willingness of authorities and residents to sanction the city as a site of multiple readings". On the contrary, "eruvim are important reminders of the diversity of social and spatial practices that permeate the Western world, a diversity that extends to include even pre-modern forms tenaciously persisting in the face of widespread secularism".

Let us turn to a parallel scenario - one that involves eruvei chatzeirot, but no eruv, a case involving multiple eruvei chatzeirot within a structure. Klein (2012) analyzes a Talmudic passage that considers whether groups of sages occupying a triclinium (in Talmudic Aramaic, a traklin) - a banquet hall - and its surrounding rooms can participate in a single eruv or must contract multiple eruvin:

Nevertheless, as in the case of the city and its diverse society, architecture can, when oriented by ritual, make a place for consensus and unity (Klein 2012: 352).

The case of a triclinium as the envelope of one or multiple eruvei chatzeirot highlights the utterly symbolic character of an eruv enclosure, with its religious re-purposing manifest only in the collection of the eruvei chatzeirot bread. Correctly contextualizing the "ritual" aspect of the eruv as manifest exclusively in the eruvei chatzeirot collection of bread leads us to reject Rapoport's (2011) contention that, by "defining a boundary that unites the characteristics of tangible bodies and virtual horizons in the making of a temporal place for a particular community, the Eruv facilitates the revelation and manifestation of transcendence through the mundane, echoed in the daily activities permitted on the holiest of days". He writes in almost mystical terms:

A bridge between heaven and earth, the sacred and the commonplace, is thus formed through the "ontological passage from one mode of being to another" (Eliade 1957: 63). Eruv thus simultaneously separates and connects the binary poles of the human experience of the holy and the commonplace; it clears a place in which the everyday human actions are imbued with transcendent meaning (Rapoport 2011).

Rapoport blurs the lines between the eruv and the eruvei chatzeirot and conflates their purposes, arguing that the space of an eruv is rendered "transcendent". The introduction of the terms "sacred" and "transcendent" is dubious. Even the eruvei chatzeirot bread has no holiness - its consumption is not subject to Jewish legal proscriptions on who, when, and how it can be eaten as are all other holy substances. It is darchei shalom - 


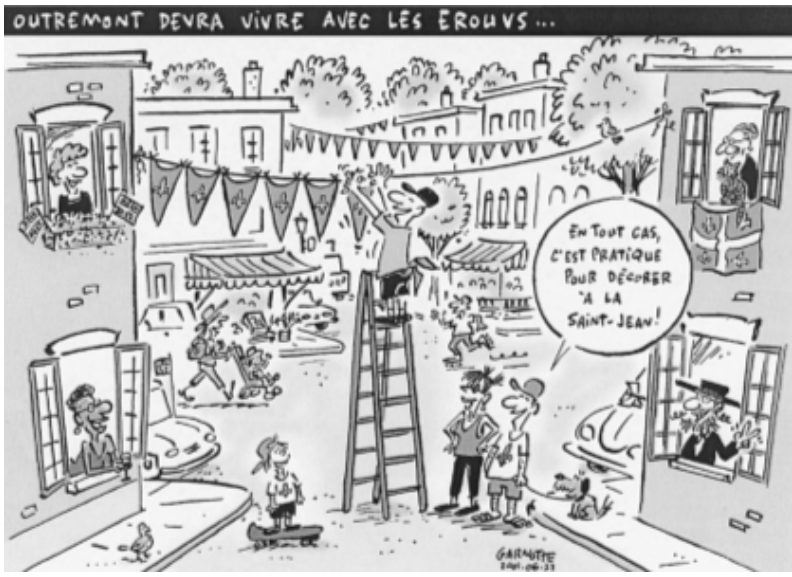

Fig. 4. An editorial cartoon highlighting the multiple purposes of an eruv enclosure

Source: Stoker (2003).

unity and community, not sanctity - that an eruv is meant to enhance. ${ }^{17}$

In the vein of a picture being worth a thousand words, a cartoon (see Fig. 4) that Stoker (2003) includes in her essay says as much as many paragraphs about the question of an eruv as "territoriality without sovereignty" and the elasticity of layers of meaning: the wire that serves one culture as an eruv serves for another culture as a flag line. Each culture (and in this specific case, religion as well) infuses an otherwise mundane and neutral object with its own layer of meaning. The person in the street is saying, "Well, at least it makes it easier to decorate for St. Jean's" (a French Catholic holiday celebrated as Nation of Quebec Day. $)^{18}$

\section{Taking to extremes}

Some opponents of eruvin have taken the conceptualization of an eruv as a territoriality very far. Cousineau (2005) cites an extreme response to the "urban vision" of the eruv-builders in North London:

\footnotetext{
${ }^{17}$ This is in interesting contrast to St. Augustine, who saw the community of Christian souls, embodied in the term domus ecclesiae ("home of the church"), as being synonymous with the sacred: without one there can't be the other. An obvious distinction is that ecclesiae at first meant the congregation or Christian community, then in the fourth century became the term used to describe a Christian house of worship (see Miller 2000: 262). Thus, the Christian community was so grounded in a religious structure that the term eventually came to represent an actual structure of the religion. The community of an eruv, on the other hand, is grounded in domesticity and represents peace among the domiciles it encompasses.

${ }^{18}$ This understanding of the character of an eruv would also argue against Susman (2009), who selectively cites specific laws and principles that she construes to assert that eruvin should be considered unconstitutional. Her essay was recently cited by Jack O'Dwyer in a polemical article urging the courts to overturn a Jan. 6, 2015, decision allowing the construction of an eruv in Westhampton, New York (O’Dwyer 2015).
}

\begin{abstract}
A former Shadow Cabinet minister made a sinister comparison between the act of eruv-making and the Nazi construction of European ghettoes. [He]... suggested that eruv users could be likened to the victims of the Holocaust whom Schindler [of Schindler's List fame] was trying to save... Schindler's protégées were depicted as powerless, impoverished, and crowded ghetto dwellers, an image that plays on negative and even frightening images of enclosure. The author's intent was that, by analogy, eruv-using Jews should be perceived in this way. Although the eruv makers argued for the eruv as a space of liberation, opponents chose to interpret it as one of restriction. Holocaust survivors wrote statements about how, for them, the poles and wires of the eruv evoked visions of concentration camp fences. Other Holocaust survivors denied this image, engaging in a debate that highlighted the formal ambiguity of the structure and its openness to a variety of interpretations (Cousineau 2005: 51-52).
\end{abstract}

Such extreme comparisons are possible only if an eruv is perceived as territoriality. This perception reminds one of the classic British film, Passport to Pimlico, as interpreted by Feigenbaum and Frenzel (2013), who note that some "protest camps" claim space and go on to "claim to be autonomous political entities or 'free' states and republics".

Our understanding of the function of an eruv would seem more in the vein of Temple's (2014) understanding of the function of rituals, which may be everyday, even mundane practices that would include creating a collection of bread within a specific space. Temple posits that, "ritual gives both continuity of beliefs or values and ensures a degree of cohesion of a particular social or religious order". While the ritual itself is primary, it "is always grounded in a topography or setting, whether locally (in the form of liturgical or ceremonial responses to particular artefacts within a space such as a religious rite or a meal) or extra-territorially (through the navigation of architectural or topographical features within a landscape or urban space)".

While Temple goes on to state that a ritual also "constitutes in some form a re-enactment of a primordial event or significant act", in the case of eruv the "significant act" (of unification) is itself repeated on a weekly basis.

Whether disclosed in a landscape, a room, or the surface of a table, the sacramental objects of ritual are brought into a sustained 
dialogue through the interaction between their various topographical settings and the bodies of the participants present (Temple 2014: 171-173).

Temple brings meals and topographies together as examples in which "ideological shifts" that "are communicated by means of their dimensional settings" allow "us to recall... certain exemplary historical/ fictive models." These mundane activities and settings are transformed into rituals. Such a ritual "gives both continuity of beliefs or values and ensures a degree of cohesion of a particular social or religious order". Presumably, when Temple wrote this chapter he did not have eruvin in mind. Yet the correlation of his analysis with the issues and concepts of eruvin is remarkable. Paradoxically (but not illogically), the enclosure of an eruv is only a precondition for the "liberation" of that space through the situational conditions of eruvei chatzeirot, the ritual practice of the eruv that is distinct and different from its boundaries.

\section{Conclusions}

One particular, and rather contentious, view of the meaning of the eruv is made by Olin (2014):

An understanding of the material nature of the eruv does not center on religious iconography but rather on spatial demarcation, a performance around a quintessential product of conceptual street art, a drawing in space (Olin 2014).

I am not sure I am willing to regard an eruv as street art performance, but the point is well taken. Contemporary urban contexts, which are largely denuded of explicit physical or ceremonial boundaries, often require substantial construction to achieve an acceptable - albeit mostly imperceptible - analog of the walls of the ancient city. Yet notwithstanding the employment of Jewish legal loopholes to allow these "walls" to remain largely notional and invisible, the walls are inherently areligious, and can serve multiple purposes. It is the eruvei chatzeirot that is the religious ritual that creates, in fact, an extra-territorial community of unity (darchei shalom), not the eruv's poles and wires (tzurat ha-petach). It is difficult, if not impossible, to see a community with a locus in a collection of bread as a territoriality. As we saw in the passage from the Jerusalem Talmud that explains the institution of eruv, the assumption of explicit territorial "demarcations" that may emerge from focusing on the boundaries of an eruv is inconsistent with the embodied meaning of eruv with respect to the shared (communal) collection of bread.

\section{References}

Auerbach, S. Z. 1999. Minchat Shlomo, Vol. 2. Jerusalem: Otzarot Shlomo.

Ballvé, T. 2011. Production of territory. Territorial masquerades [online], [cited 19 April 2017]. Available from Internet: http://territorialmasquerades.net/production-of-territory

Bechhofer, Y. G. 1998. The contemporary eruv: eruvin in modern metropolitan areas. Jerusalem: Feldheim.

Bergman, E. 2002. The rewir or Jewish district and the eyruv, Studia Judaica 5(1): 85-97.

Brenner, N.; Elden, S. 2009. Henri Lefebvre on state, space and territory, International Political Sociology 3(4): 353-377. https://doi.org/10.1111/j.1749-5687.2009.00081.x

Cousineau, J. 2005. Rabbinic urbanism in London: rituals and the material culture of the Sabbath, Jewish Social Studies, New Series 11(3): 36-57.

https://doi.org/10.2979/JSS.2005.11.3.36

Cowan, R. 2005. The dictionary of urbanism. Chicago: Streetwise Press.

Di-Trani, I. 1966. Piskei HaRid, Vol. 2. Jerusalem: Machon HaTalmud HaYisraeli HaShalem.

Eliade, M. 1957. Das heilige und das profane: Vom wesen des religiősen. Hamburg: Rowohlt.

Eruvin. 1959. Talmud Bavli [The Babylonian Talmud]. New York: Gur-Ary.

Eruvin. 1970. Talmud Yerushalmi [The Jerusalem Talmud]. Jerusalem: B. B.

Exodus. 1985. New Jewish Publication Society of America Tanakh [Bible]. Philadelphia: Jewish Publication Society of America.

Feigenbaum, A.; Frenzel, F. 2013. Protest camps. London, GBR: Zed Books.

Fonrobert, C. 2004. From separatism to urbanism: the Dead Sea scrolls and the origins of the rabbinic 'eruv, Dead Sea Discoveries 11(1): 43-71. https://doi.org/10.1163/156851704323017430

Fonrobert, C. 2005. Political symbolism of the eruv, Jewish Social Studies, New Series 11(3): 9-35. https://doi. org/10.2979/JSS.2005.11.3.9

Fonrobert, C. 2009. The new spatial turn in Jewish Studies, AJS Review 33(1): 155-164. https://doi.org/10.1017/S0364009409000075

Greenberg, I. 1993. The Jewish way: living the holidays. New York: Touchstone.

Hecht, R. D. 2007. Active versus passive pluralism: a changing style of civil religion?, Annals of the American Academy of Political and Social Science 612: 133-151.

Herz, M. 2008. "Eruv" urbanism: towards an alternative "Jewish Architecture" in Germany, in A. Nocke, A. Lipphardt, J. Anna, J. Brauch (Eds.). Jewish topographies: visions of space, traditions of place. London: Routledge, 43-61.

Hirsch, S. R. 2005. The Hirsch Chumash: Sefer Shemos. Jerusalem: Feldheim.

Hutterer, B. 2016. Parashat ha'ibbur and the episode of the drawing: on eruv maps and their publication [online], [cited 19 July 2016]. Available from Internet: https://safranim.com

Kayyara, S. 1888. Halachot Gedoloth. Berlin: M'kize Nirdamim. 
Klein, G. P. 2012. Torah in triclinia: the rabbinic banquet and the significance of architecture, Jewish Quarterly Review 102(3): 325-370.

Lees, S. H. 2007. Jewish space in suburbia: interpreting the eruv conflict in Tenafly, New Jersey, Contemporary Jewry 27(1): 42-79. https://doi.org/10.1007/BF02965546

Lewin, N. 2004. Protecting Jewish observance in secular courts, Tradition: a Journal of Orthodox Jewish Thought 38(1): 95111.

Mann, B. E. 2012. Space and place in Jewish studies. Rutgers: Rutgers University Press.

Megillah. 1959. Talmud Bavli [The Babylonian Talmud]. New York: Gur-Ary.

Megillah. 1970. Talmud Yerushalmi [The Jerusalem Talmud]. Jerusalem: B. B.

Miller, M. C. 2000. The Bishop's palace: architecture and authority in Medieval Italy. Ithaca: Cornell University Press.

O’Dwyer, J. 2015. UCLA law prof says eruvim are unconstitutional [online], [cited 19 April 2017]. Available from Internet: http://www.odwyerpr.com/story/public/3840/2015-01-12/ ucla-law-prof-says-eruvim-are-unconstitutional.html

Olin, M. 2014. The materiality of the imperceptible, in S. M. Promey (Ed.). Sensational religion: sensory cultures in material practice. New Haven: Yale University Press, 183-202.

Proverbs. 1985. New Jewish Publication Society of America Tanakh [Bible]. Philadelphia: Jewish Publication Society of America.

Rapoport, M. 2011. Creating place, creating community: the intangible boundaries of the Jewish "Eruv", Environment and Planning D: Society and Space 29(5): 891-904. https://doi.org/10.1068/d17509

Religion. 1972. The New York Times, 2 April 1972 [online], [cited 16 August 2016]. Available from Internet: http://www. nytimes.com/1972/04/02/archives/space-for-carrying-jews. html

Roberts, M. 2013. The geography of international terrorism: an introduction to spaces and places of violent non-state groups. By Richard M. Medina and George F. Hepner. Boca Raton, FL: CRC Press, 2013. ISBN 978-1-4398-8686-1. Maps. Photographs. Sources cite. Index. Pp. Xiii, 244. \$79.95, Journal of Strategic Security 6(4): 106-108. https://doi.org/10.5038/1944-0472.6.4.7

Rotenstein, D. 2010. Mapping MoCo's Jewish courtyards: the eruvim (updated) [online], [cited 19 July 2016]. Available from Internet: http://blog.historian4hire.net/2010/10/20/ mapping-moco-eruvim

Sack, R. D. 1986. Human territoriality: its theory and history. Cambridge (U.K.): Cambridge University Press.
Sack, R. D. 2010. Geography as a tool for developing the mind: a theory of place-making. Lewiston (N.Y.): Edwin Mellen Press.

Schlör, J. 2007. Introduction, in J. Šiaučiūnaitė-Verbickienè, L. Lempertienè (Eds.). Jewish space in Central and Eastern Europe: day-to-day history. Newcastle: Cambridge Scholars Publishing, 1-6.

Schnall, E. 2011. A tale of two cities? Shushan Purim in modern-day Yerushalayim [online], [cited 16 June 2016]. The Center for the Jewish Future, Yeshiva University. Available from Internet: http://www.yutorah.org/togo/Purim/articles/Purim_To_Go_-_5771_Rabbi_Schnall.pdf

Searle, J. R. 1995. The construction of social reality. New York: The Free Press.

Slonim, Z. D. 1979. Sha'arei Halachah. Jerusalem: Machon Cheker Halachah.

Smith, B. 2007. On place and space: the ontology of eruv, in C. Kanzian (Ed.). Cultures: conflict - analysis - dialogue. Frankfurt: Ontos Verlag, 403-416.

Stoker, V. 2003. Drawing the line: Hasidic Jews, eruvim, and the public space of Outremont, Quebec, History of Religions 43(1): 18-49. https://doi.org/10.1086/381321

Susman, A. L. 2009. Strings attached: an analysis of the eruv under the religion clauses of the first amendment and the religious land use and institutionalized persons act, University of Maryland Law Journal of Race, Religion Gender and Class 9(1): 93-134.

Temple, N. 2011. Renovatio urbis: architecture, urbanism and ceremony in the Rome of Julius II. 1st ed. Routledge, Hoboken.

Temple, N. 2014. Rites of intent: the participatory dimension of the city, in K. Gulliver, H. Toth (Ed.). Cityscapes in history. Farnham: Ashgate, 153-178.

Vincent, P.; Warf, B. 2002. Eruvim: Talmudic places in a postmodern world, Transactions of the Institute of British Geographers, New Series 27(1): 30-51.

\section{ROBERT Y. G. BECHHOFER}

Robert (Yosef Gavriel) Bechhofer teaches Judaic Studies at Excelsior College in New York. He is a PhD candidate at the University of Huddersfield School of Art, Design and Architecture. He has been involved with eruvin, a multidisciplinary field that is a nexus of Judaic and Urban Studies, for many years, and is considered one of the world's foremost experts on eruvin. He has published several books and many essays that deal with the interfaces of various issues in Judaic Studies and other academic and professional studies. His book: The Contemporary Eruv: Eruvin in Modern Metropolitan Areas (First Edition, 1998; Third Edition, 2013) is widely regarded as one of the seminal works in the field. 